\title{
Electronic structures of ruthenium complexes encircling non-innocent ligand assembly
}

\author{
AMIT DAS, DIPANWITA DAS, TANAYA KUNDU and GOUTAM KUMAR LAHIRI* \\ Department of Chemistry, Indian Institute of Technology Bombay, Powai, Mumbai 400 076, India \\ e-mail: lahiri@chem.iitb.ac.in
}

\begin{abstract}
Electronic structural forms of selected mononuclear and dinuclear ruthenium complexes encompassing redox non-innocent terminal as well as bridging ligands have been addressed. The sensitive valence and spin situations of the complexes have been established in the native and accessible redox states via detailed analysis of their crystal structures, electrochemistry, UV/VIS/NIR spectroelectrochemistry, EPR signatures at the paramagnetic states and DFT calculations. Mononuclear complexes exhibit significant variations in valence and spin distribution processes based on the simple modification of the non-innocent ligand frameworks as well as electronic nature of the co-ligands, $\sigma$-donating or $\pi$-accepting. Dinuclear complexes with modified pyrazine, $p$-quinone and azo-derived redox-active bridging ligands show complex features including redoxinduced electron-transfer (RIET), remote metal to metal spin-interaction in a three-spin metal-bridge-metal arrangement as well as electron-transfer driven chemical transformation (EC).
\end{abstract}

Keywords. Ruthenium; non-innocent ligand; spectroelectrochemistry; EPR spectroscopy; DFT calculations.

\section{Introduction}

The ligands which can exhibit more than one redox states within the experimentally accessible potential range particularly on coordination to metal ions are considered to be 'non-innocent' or more specifically 'redox non-innocent'. The concept of 'suspect' (or 'non-innocent') ligand was first introduced by Jørgensen in 1964 in order to address the redox activity of simple molecules like $\mathrm{O}_{2}$ and $\mathrm{NO}^{1}$ as both of them in principle can exist in three oxidation states as shown in scheme 1.

Subsequently, Ward and McCleverty defined this more precisely as non-innocent behaviour of the ambivalence ligands, as the behaviour of such ligands primarily depends on the nature of the metal counterpart as well as other co-ligands within the specific molecular frameworks. ${ }^{2,3}$

The variable redox states of metal ion $\left(\mathrm{M}^{\mathrm{n}} / \mathrm{M}^{\mathrm{n}+1}\right)$ and non-innocent ligand $\left(\mathrm{L}^{\mathrm{n}} / \mathrm{L}^{\mathrm{n}-1}\right)$ can give rise to (i) barrierless resonance form or (ii) valence tautomerism, this in turn brings into the challenging scenario of establishing the precise valence and spin configurations of such complexes.

$$
\left\{\mathrm{M}^{\mathrm{n}}-\mathrm{L}^{\mathrm{n}}\right\} \longleftrightarrow\left\{\mathrm{M}^{\mathrm{n}+1}-\mathrm{L}^{\mathrm{n}-1}\right\},
$$

$$
\left\{\mathrm{M}^{\mathrm{n}}-\mathrm{L}^{\mathrm{n}}\right\} \rightleftharpoons\left\{\mathrm{M}^{\mathrm{n}+1}-\mathrm{L}^{\mathrm{n}-1}\right\} .
$$

In this context, the electronic structural aspects of a wide variety of metal complexes incorporating different redox non-innocent ligands have been investigated in recent years via detailed experimental and theoretical studies. ${ }^{4}$ The present study gives an outline of our recent work in the direction of assigning the valence and spin distribution processes in accessible redox states of selective mononuclear and dinuclear ruthenium complexes incorporating modified quinonoid, pyrazine and azo-derived non-innocent ligands (scheme 2).

The preferential choice of ruthenium ion for our studies is essentially due to the following two reasons: (i) easy to achieve mutliple redox states, $\mathrm{Ru}^{\mathrm{II}}, \mathrm{Ru}^{\mathrm{III}}, \mathrm{Ru}^{\mathrm{IV}}$ within the accessible potential range ${ }^{5}$ and (ii) closeness of energy of the frontier orbitals of the ruthenium ion and these non-innocent ligands (scheme 2 ) $^{6,7}$ results in considerable mixing of orbitals in the resultant MOs in respective complexes. This quite often develops the complicated resonance situation instead of one specific

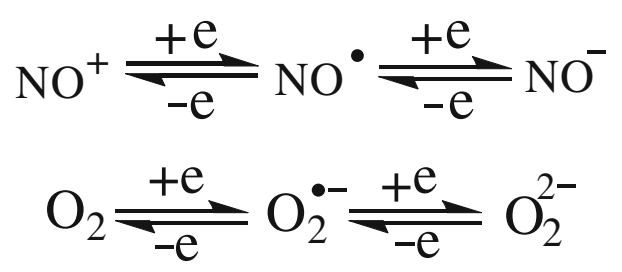

Scheme 1. Different redox forms of $\mathrm{NO}$ and $\mathrm{O}_{2}$. 
<smiles>N=C1C=CC=CC1=O</smiles>

$\mathbf{L}_{1}$<smiles>c1ccc(-c2nc(-c3ccccn3)c(-c3ccccn3)nc2-c2ccccn2)nc1</smiles>

$\mathrm{BL}_{1}$<smiles>CC(C)(C)C1=CC(=Nc2ccccc2)C(=O)C(C(C)(C)C)=C1</smiles>

$\mathbf{L}_{2}$<smiles></smiles>

$\mathrm{BL}_{2}$<smiles>CC(C)(C)C1=CC(=O)C(=O)C(C(C)(C)C)=C1</smiles>

$\mathbf{L}_{3}$<smiles>c1ccc(/N=N/c2ccccn2)nc1</smiles>

$\mathrm{BL}_{3}$

Scheme 2. Quinone, pyrazine and azo based non-innocent terminal (L) and bridging (BL) ligands.

configuration which in effect introduces the difficulty in assigning the precise electronic structural forms. ${ }^{8}$ However, the detailed experimental studies in combination with DFT calculations facilitate in reaching to a reasonably conclusive state regarding the electronic structural forms of this class of complexes. ${ }^{9}$

\section{Results and discussion}

The cis-quinonoid ligands, $\mathrm{L}_{1}-\mathrm{L}_{3}$ and the bridging ligands $\left(\mathrm{BL}_{1}-\mathrm{BL}_{3}\right)$ were chosen for the development of selective monomeric and dimeric ruthenium complexes, respectively, in combination with different co-ligands.

\subsection{Mono-quinonoid complexes, a two-centred redox} system: Simple modification makes a dramatic change

The diamagnetic and electrically neutral mononuclear complexes, $\left[\mathrm{Ru}(\mathrm{acac})_{2}\left(\mathrm{~L}_{1}\right)\right](\mathbf{1})$ and $\left[\mathrm{Ru}(\mathrm{acac})_{2}\left(\mathrm{~L}_{2}\right)\right](\mathbf{2})$ comprising of iminoquinonoid ligands, $\mathrm{L}_{1}$ and $\mathrm{L}_{2}$, respectively, and the ruthenium fragment, $\left\{\operatorname{Ru}(\mathrm{acac})_{2}\right\}$ $\left(\right.$ acac $^{-}=$acetylacetonato $=2,4$-pentanedionato $)$ were synthesized. ${ }^{10}$ The different redox states of noninnocent quinonoid ligands (scheme 3 ) in combination with redox active ruthenium ion leads to three
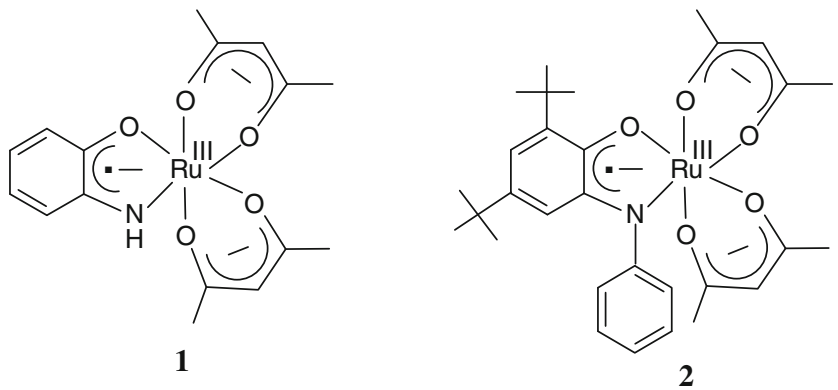

possible electronic structural forms in the native state of 1 or 2: $\left\{\mathrm{Ru}^{\mathrm{II}}-\mathrm{L}^{0}\right\}$ or $\left\{\mathrm{Ru}^{\mathrm{III}}-\mathrm{L}^{\bullet-}\right\}$ or $\left\{\mathrm{Ru}^{\mathrm{IV}}-\mathrm{L}^{2-}\right\}$. However, crystal structures of $\mathbf{1}$ and $\mathbf{2}$ reveal that the sensitive $\mathrm{C}-\mathrm{O} / \mathrm{C}-\mathrm{N} /$ meta$-\mathrm{C}-\mathrm{C}$ bond distances of coordinated $\mathrm{L}_{1}$ and $\mathrm{L}_{2}$ of $1.291(4) \AA / 1.340(4) \AA / 1.354 \AA$ and 1.291(3) $\AA /$ 1.354(3) $\AA / 1.361 \AA$, respectively, fit fairly well with the intermediate semiquinone description $\mathrm{L}^{\bullet-}{ }^{11}$ This essentially establishes the antiferromagnetically coupled $\left\{\mathrm{Ru}^{\mathrm{III}}-\mathrm{L}^{\bullet-}\right\}$ configuration of $\mathbf{1}$

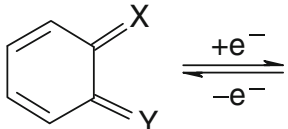

$\mathbf{L}^{\mathbf{0}}$<smiles></smiles>

$\mathbf{L}^{\prime-}$<smiles>[X]c1ccccc1I</smiles>

$\mathbf{L}^{2-}$

$\mathbf{L}_{1}: X=\mathrm{O}, \mathrm{Y}=\mathrm{NH}$

$\mathbf{L}_{2}: X=O, Y=N P h$

Scheme 3. Different redox states of L. 
and 2 , instead of alternate valence configurations of $\left\{\mathrm{Ru}^{\mathrm{II}}-\mathrm{L}^{0}\right\}$ and $\left\{\mathrm{Ru}^{\mathrm{IV}}-\mathrm{L}^{2-}\right\}$.

Both $\mathbf{1}$ and $\mathbf{2}$ display one reversible one-electron oxidation and one reversible one-electron reduction within the experimental potential window of $\pm 2.0 \mathrm{~V}$ vs SCE. Though both $\mathbf{1}$ and $\mathbf{2}$ exhibit the same native state configuration of $\left[\mathrm{Ru}^{\mathrm{III}}(\mathrm{acac})_{2}\left(\mathrm{~L}^{\bullet-}\right)\right]$, their electronic structural forms in the accessible redox state are drastically different. In case of $\mathbf{1}$ both the oxidation and reduction primarily involve the ligand centred orbitals leaving the unpaired spin on the metal ion as has been evidenced from the typical $\mathrm{Ru}^{\mathrm{III}}$-based $\left(\mathrm{t}_{2 \mathrm{~g}}^{5}\right)$ EPR signals ${ }^{12}$ for the oxidized $\left[\mathrm{Ru}^{\mathrm{III}}(\mathrm{acac})_{2}\left(\mathrm{~L}_{1}^{\mathrm{o}}\right)\right]^{+}\left(\mathbf{1}^{+}\right)(<g>=2.103$ $\left.\left[<g>=\left\{\left(g_{1}^{2}+g_{2}^{2}+g_{3}^{2}\right) / 3\right\}^{1 / 2}\right)\right] ; \Delta g=0.305(\Delta g=$ $\left.\left.g_{1}-g_{3}\right)^{10 \mathrm{a}}\right)$ and reduced $\left[\mathrm{Ru}^{\mathrm{III}}(\mathrm{acac})_{2}\left(\mathrm{~L}_{1}^{2-}\right)\right]^{-}\left(\mathbf{1}^{-}\right)(<g>$ : 2.026; $\Delta g$ : 0.205). The larger $g$-anisotropy $(\Delta g)$ in $\mathbf{1}^{+}$ as compared to $\mathbf{1}^{-}$implies greater localization of the unpaired spin onto the Ru-centre in $\mathbf{1}^{+}$.

On moving from 1 to 2 , a dramatic change in electronic configurations for the oxidized $\left(2^{+}\right)$and reduced $\left(\mathbf{2}^{-}\right)$states has been observed. Unlike $\mathbf{1}$, here the oxidation or reduction takes place preferentially at the metal site leading to the ligand-based unpaired spin in $\left[\mathrm{Ru}^{\mathrm{IV}}(\mathrm{acac})_{2}\left(\mathrm{~L}_{2}^{--}\right)\right]^{+}\left(\mathbf{2}^{+}\right)$or $\left[\mathrm{Ru}^{\mathrm{II}}(\operatorname{acac})_{2}\left(\mathrm{~L}_{2}^{\bullet-}\right)\right]^{-}$ $\left(\mathbf{2}^{-}\right)$as evidenced by the free radical EPR signals with $g \sim 2.0$. Spin-density plots of the DFT optimized $\mathbf{2}^{+}$(Mulliken spin densities: Ru:0.184, $\mathrm{L}_{2}: 0.741$, acac:0.073) and $\mathbf{2}^{-}$(Mulliken spin densities: Ru:0.282, $\mathrm{L}_{2}: 0.691$, acac:0.019) also confirm the localization of the unpaired spin largely on the ligand moiety (scheme 4).

Thus, simple chemical modification in the quinonoid ligand frameworks, $\mathrm{L}_{1}=\mathrm{X}=\mathrm{O}, \mathrm{Y}=\mathrm{NH}$ in $\mathbf{1}$ to $\mathrm{L}_{2}=\mathrm{X}=\mathrm{O}, \mathrm{Y}=\mathrm{NPh}$ in $\mathbf{2}$ (scheme 3 ) completely alters the redox behaviours of the complexes.

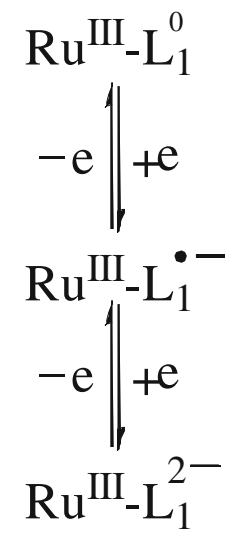

$1^{\mathrm{n}}$
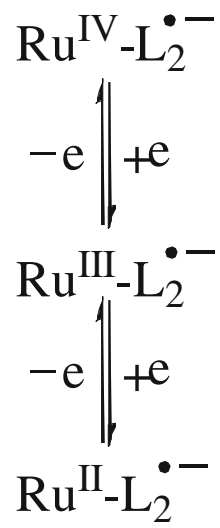

$2^{\mathrm{n}}$
Scheme 4. Electronic configurations of $\mathbf{1}^{\mathrm{n}}$ and $\mathbf{2}^{\mathrm{n}}$ in different redox states.
2.2 Bis-quinonoid complexes, a three-centred redox system: Effect of ancillary ligands

The electrically neutral bis-quinonoid complexes, $\left[\mathrm{Ru}^{\mathrm{III}}(\mathrm{acac})\left(\mathrm{L}_{2}^{--}\right)_{2}\right](3)$ and $\left[\mathrm{Ru}^{\mathrm{II}}(\mathrm{bpy})\left(\mathrm{L}_{2}^{\bullet-}\right)_{2}\right](\mathbf{4})$ (bpy = $2,2^{\prime}$-bipyridine) comprising of three potential redox sites,

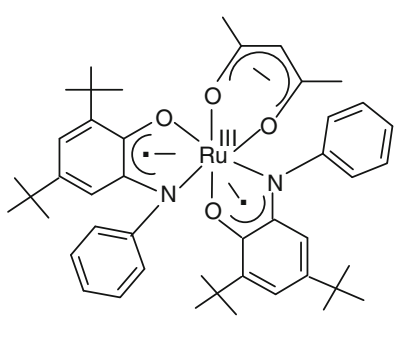

3

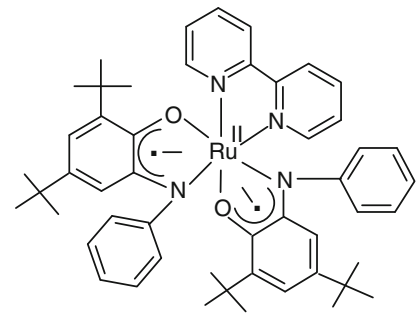

4 two iminosemiquinone moieties $\left(\mathrm{L}_{2}^{\cdot-}\right)$ and the metal ion. ${ }^{10 b, 13}$ Strong antiferromagnetic coupling between the neighbouring $\mathrm{Ru}^{\mathrm{III}}$ and $\mathrm{L}^{--}$centres in the threespin system of 3 results in a doublet $(S=1 / 2)$ ground state with one unpaired spin onto the second $\mathrm{L}^{\bullet-}$. However, the molecule is EPR silent at room temperature due to the complex magnetic interactions. The expected ligand-centred free-radical EPR is observed at low temperatures with $g_{\text {iso }}=1.99$ in solution and 1.98 in solid, implying an up-down-up spin situation with antiferromagnetic coupling between the neighbouring spins. DFT supported metal based first oxidation and first reduction lead to the formation of spin-coupled diamagnetic $\left[\mathrm{Ru}^{\mathrm{IV}}(\mathrm{acac})\left(\mathrm{L}^{\bullet-}\right)_{2}\right]^{+}\left(3^{+}\right)$and $\left[\mathrm{Ru}^{\mathrm{II}}(\mathrm{acac})\left(\mathrm{L}^{--}\right)_{2}\right]^{-}$ $\left(3^{-}\right)$, respectively. The second reduction however occurs at the ligand site resulting in a doublet $(\mathrm{S}=1 / 2)$ system, $\left[\mathrm{Ru}^{\mathrm{II}}(\mathrm{acac})\left(\mathrm{L}^{\bullet-}\right)\left(\mathrm{L}^{2-}\right)\right]^{2-}\left(3^{2-}\right)$ with the unpaired spin residing onto the ligand as evidenced by the free radical EPR signal with $g_{\text {iso }}=2.004$.

On replacing the $\sigma$-donating $\mathrm{acac}^{-}$co-ligand in the framework of $\mathbf{3}$ by the $\pi$-accepting bpy ligand in 4 , the ruthenium ion stabilizes in $\mathrm{Ru}(\mathrm{II})$ state and the native state configuration alters to paramagnetic $\left[\mathrm{Ru}^{\mathrm{II}}(\mathrm{bpy})\left(\mathrm{L}^{\bullet-}\right)_{2}\right] .^{7}$ The complex 4 shows free radical EPR at $300 \mathrm{~K}$ with $g \sim 2.0$ but without any halffield signal as otherwise expected for the bi-radical system. However, the complex is found to be EPRsilent at $4 \mathrm{~K}$ revealing a spin-coupled state particularly at low temperature. This has also been supported by the variable temperature magnetic measurements. Based on the detailed experimental results and DFT calculations, the spin-state of $\mathbf{4}$ having two $\mathrm{L}^{--}$centres around the closed shell $\mathrm{Ru}(\mathrm{II})\left(\mathrm{t}_{2 \mathrm{~g}}^{6}\right)$ ion can be best attributed to a singlet $(S=0)$ ground state with a thermally accessible low-lying excited triplet $(S=1)$ state 
which yields paramagnetic feature at higher temperatures and diamagnetic behaviour near $4 \mathrm{~K}$. The redoxactive ruthenium(II) ion and coordinated two $\mathrm{L}_{2}^{--}$in $\mathbf{4}$ are likely to participate in accessible electron-transfer processes. However, experimental (UV/VIS/NIR or EPR spectroelectrochemistry) and DFT results collectively suggest the preferential involvement of $\mathrm{L}_{2}$ based orbitals in the redox chain: $\left[\mathrm{Ru}^{\mathrm{II}}(\mathrm{bpy})\left(\mathrm{L}_{2}^{0}\right)_{2}\right]^{2+}$ $\left(4^{2+}\right) \rightleftharpoons\left[\mathrm{Ru}^{\mathrm{II}}(\mathrm{bpy})\left(\mathrm{L}_{2}^{--}\right)\left(\mathrm{L}_{2}^{0}\right)\right]^{+}\left(\mathbf{4}^{+}\right) \rightleftharpoons\left[\mathrm{Ru}^{\mathrm{II}}(\mathrm{bpy})\right.$ $\left.\left(\mathrm{L}_{2}^{\bullet-}\right)_{2}\right] \quad(\mathbf{4}) \rightleftharpoons\left[\mathrm{Ru}^{\mathrm{II}}(\mathrm{bpy})\left(\mathrm{L}_{2}^{\cdot-}\right)\left(\mathrm{L}_{2}^{2-}\right)\right]^{-}$(major)/ $\left[\mathrm{Ru}^{\mathrm{III}} \text { (bpy) }\left(\mathrm{L}_{2}^{2-}\right)_{2}\right]^{-}$(minor) $\left(\mathbf{4}^{-}\right)$leaving the ruthenium(II) ion as a virtual redox-innocent entity.

\subsection{Tris-quinonoid complex, a four-centred redox system: Invariant ruthenium(III)-semiquinone state}

The crystal structure analysis of the tris-iminoquinone complex, 5 reveals that all the three ligands exist in intermediate semiquinone state, resulting in a four-spin situation in $\mathrm{Ru}^{\mathrm{III}}\left(\mathrm{L}_{2}^{\cdot-}\right)_{3} .^{10 \mathrm{~b}}$ The mutual antiferromagnetic coupling of the four spins leads to a diamagnetic $\mathrm{S}=0$ ground state. $\mathbf{5}$ shows successive two oxidations and two reductions within the potential range $\pm 2.0 \mathrm{~V}$ vs $\mathrm{SCE}$ in $\mathrm{CH}_{3} \mathrm{CN}$. The detailed experimental and

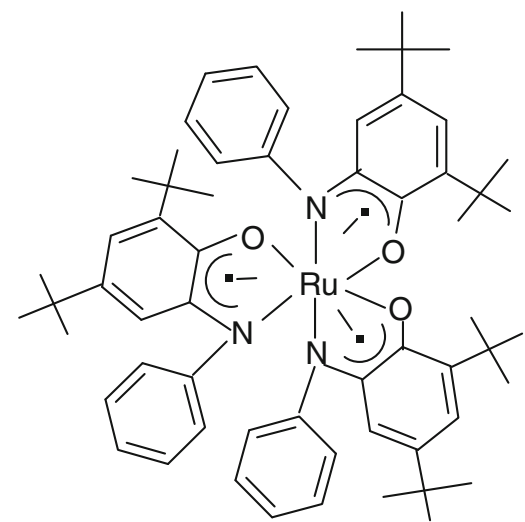

5

DFT investigations suggest ligand centred preferential electron-transfer processes, $\left[\mathrm{Ru}^{\mathrm{III}}\left(\mathrm{L}^{\bullet-}\right)\left(\mathrm{L}^{0}\right)_{2}\right]^{2+}\left(\mathbf{5}^{2+}\right) \rightleftharpoons\left[\mathrm{Ru}^{\mathrm{III}}\left(\mathrm{L}^{\bullet-}\right)_{2}\left(\mathrm{~L}^{0}\right)\right]^{+}$ $\left(5^{+}\right) \rightleftharpoons\left[\mathrm{Ru}^{\mathrm{III}}\left(\mathrm{L}^{\bullet-}\right)_{3}\right](\mathbf{5}) \rightleftharpoons\left[\mathrm{Ru}^{\mathrm{III}}\left(\mathrm{L}^{\bullet-}\right)_{2}\left(\mathrm{~L}^{2-}\right)\right]^{-}$ $\left(\mathbf{5}^{-}\right) \rightleftharpoons\left[\mathrm{Ru}^{\mathrm{III}}\left(\mathrm{L}^{-}\right)\left(\mathrm{L}^{2-}\right)_{2}\right]^{2-}\left(\mathbf{5}^{2-}\right)$, leaving the ruthenium(III)-iminosemiquinone $\left\{\mathrm{Ru}^{\mathrm{III}}-\mathrm{L}^{{ }^{-}}\right\}$as a remarkable invariable entity along the redox chain.

\subsection{Diruthenium complexes incorporating} non-innocent bridging and ancillary ligands, a five-centred redox system: Iminoquinone vs quinone

Complexes $\quad\left[(\mathrm{Cl})\left(\mathrm{L}_{2}\right) \mathrm{Ru}^{\mathrm{III}}\left(\mu-\mathrm{BL}_{1}\right) \mathrm{Ru}^{\mathrm{III}}\left(\mathrm{L}_{2}\right)(\mathrm{Cl})\right]\left(\mathrm{PF}_{6}\right)_{2}$ (6) and $\left[(\mathrm{Cl})\left(\mathrm{L}_{3}\right) \mathrm{Ru}^{\mathrm{II}}\left(\mu-\mathrm{BL}_{1}\right) \mathrm{Ru}^{\mathrm{II}}\left(\mathrm{L}_{3}\right)(\mathrm{Cl})\right]$ (7) incorporating non-innocent bridging ligand $\mathrm{BL}_{1}\left(\mathrm{BL}_{1}=\right.$
2,3,5,6-Tetrakis(2-pyridyl)pyrazine) and non-innocent ancillary ligands $\mathrm{L}_{2}$ and $\mathrm{L}_{3}$, respectively, were synthesized and structurally characterized. ${ }^{14}$ The redox non-
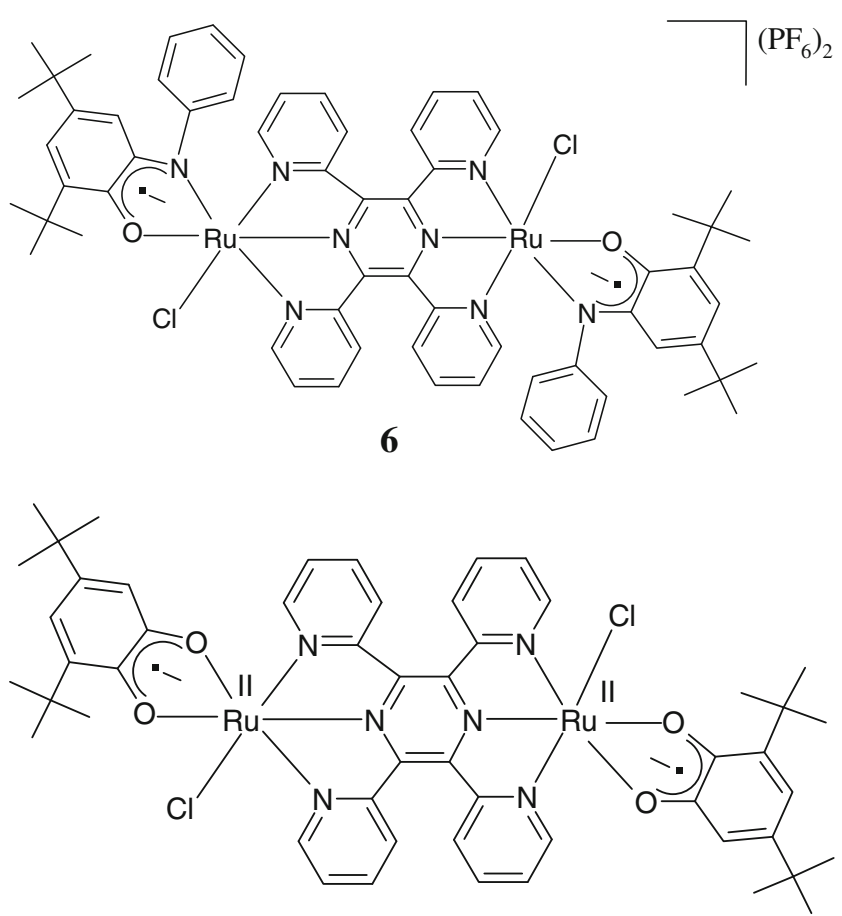

7

innocent features of $\mathrm{BL}_{1}$ (scheme 5), ${ }^{15} \quad \mathrm{~L}_{2} / \mathrm{L}_{3}$ (scheme 3 ) in combination with the ruthenium ion introduce a complex situation of five-redox centres within the same molecular framework of $\mathbf{6}$ or 7. Crystal structure analysis reveals that in both $\mathbf{6}$ and $\mathbf{7}$ the bridging ligand $\mathrm{BL}_{1}$ and the ancillary ligand $\mathrm{L}_{2}$ or $\mathrm{L}_{3}$ exist in fully oxidized $\mathrm{BL}_{1}^{0}$ and intermediate semiquinone $\left(\mathrm{L}^{--}\right)$ state, respectively. The more basic nature of the iminoquinone ligand $\left(\mathrm{O}, \mathrm{N}\right.$ donors of $\left.\mathrm{L}_{2}\right)$ as compared to the simple $\mathrm{O}, \mathrm{O}$ donors of $\mathrm{L}_{3}$ stabilizes the ruthenium ions in +3 and +2 oxidation states in $\mathbf{6}$ and $\mathbf{7}$, respectively.

The strong antiferromagnetic coupling between the unpaired spins on $\mathrm{Ru}^{\mathrm{III}}$ and $\mathrm{L}_{2}^{\bullet-}$ at each terminal position of $\left[(\mathrm{Cl})\left(\mathrm{L}_{2}^{\bullet-}\right) \mathrm{Ru}^{\mathrm{III}}\left(\mu-\mathrm{BL}_{1}^{0}\right) \mathrm{Ru}^{\mathrm{III}}\left(\mathrm{L}_{2}^{\bullet-}\right)(\mathrm{Cl})\right]^{2+}(\mathbf{6})$ results in an overall diamagnetic $(S=0)$ ground state. It shows two reversible oxidations and four reversible reductions within the experimental potential range of $\pm 2.0 \mathrm{~V} v s$ SCE in acetonitrile. $\mathrm{Ru}^{\mathrm{III}}$ based anisotropic EPR, intense IVCT (IVCT $=$ intervalence charge transfer) band at $1850 \mathrm{~nm}$ and metal dominated spin (Mulliken spin distribution: $\mathrm{Ru}, 1.116 ; \mathrm{Cl}, 0.186$, and $\mathrm{BL}_{1}$, -0.280 ) of the first oxidized state imply a RIET (redoxinduced electron transfer) process. ${ }^{16}$ This involves the oxidation of both the iminosemiquinone $\left(\mathrm{L}^{\bullet-}\right)$ ligands accompanied by one-step metal reduction resulting in a net one-electron oxidized product, $\left[(\mathrm{Cl})\left(\mathrm{L}_{2}^{0}\right) \mathrm{Ru}^{\mathrm{III}}(\mu\right.$ $\left.\left.\mathrm{BL}_{1}^{0}\right) \mathrm{Ru}^{\mathrm{II}}\left(\mathrm{L}_{2}^{0}\right)(\mathrm{Cl})\right]^{3+}\left(\boldsymbol{6}^{+}\right)$. The metal based simple 


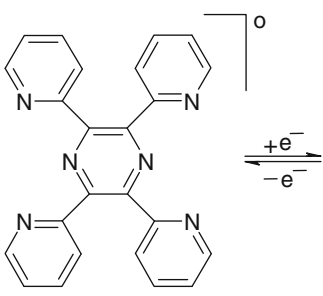

$\mathrm{BL}_{1}{ }^{0}$

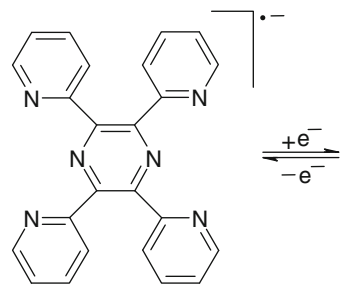

$\mathrm{BL}_{1}^{\bullet-}$

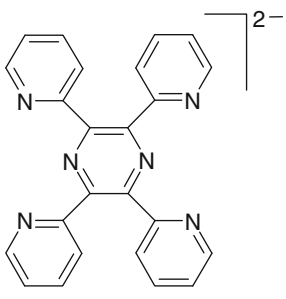

$\mathrm{BL}_{1}^{2-}$

Scheme 5. Different redox states of $\mathrm{BL}_{1}$.

second oxidation however yields a diruthenium(III) species $\left[(\mathrm{Cl})\left(\mathrm{L}_{2}^{0}\right) \mathrm{Ru}^{\mathrm{III}}\left(\mu-\mathrm{BL}_{1}^{0}\right) \mathrm{Ru}^{\mathrm{III}}\left(\mathrm{L}_{2}^{0}\right)(\mathrm{Cl})\right]^{4+}\left(6^{2+}\right)$. Reduction, on the other hand, takes place in rather sequential manner starting with the metal centres, yielding the intermediate mixed valent iminosemiquinone complex, $\left[(\mathrm{Cl})\left(\mathrm{L}_{2}^{\cdot-}\right) \mathrm{Ru}^{\mathrm{III}}\left(\mu-\mathrm{BL}_{1}^{0}\right) \mathrm{Ru}^{\mathrm{II}}\left(\mathrm{L}_{2}^{\bullet-}\right)(\mathrm{Cl})\right]^{+}\left(\mathbf{6}^{-}\right)$ with free radical EPR signature followed by isovalent diruthenium(II) iminosemiquinone complex $\left[(\mathrm{Cl})\left(\mathrm{L}_{2}^{\bullet-}\right) \mathrm{Ru}^{\mathrm{II}}\left(\mu-\mathrm{BL}_{1}^{0}\right) \mathrm{Ru}^{\mathrm{II}}\left(\mathrm{L}_{2}^{\bullet-}\right)(\mathrm{Cl})\right] \quad\left(6^{2-}\right) . \quad$ Subsequent to metal based two-step reductions to $\mathrm{Ru}^{\mathrm{II}} \mathrm{Ru}^{\mathrm{II}}$ state, the bridging ligand $\left(\mathrm{BL}_{1}\right)$ undergoes twostep reduction, $\mathrm{BL}_{2}^{0} \rightarrow \mathrm{BL}_{2}^{--}$in $\left[(\mathrm{Cl})\left(\mathrm{L}_{2}^{--}\right) \mathrm{Ru}^{\mathrm{II}}(\mu-\right.$ $\left.\left.\mathrm{BL}_{1}^{\cdot-}\right) \mathrm{Ru}^{\mathrm{II}}\left(\mathrm{L}_{2}^{\cdot-}\right)(\mathrm{Cl})\right]^{-}\left(6^{3-}\right)$ and $\mathrm{BL}_{2}^{\cdot-} \rightarrow \mathrm{BL}_{2}^{2-}$ in $\left[(\mathrm{Cl})\left(\mathrm{L}_{2}^{\bullet-}\right) \mathrm{Ru}^{\mathrm{II}}\left(\mu-\mathrm{BL}_{1}^{2-}\right) \mathrm{Ru}^{\mathrm{II}}\left(\mathrm{L}_{2}^{\bullet-}\right)(\mathrm{Cl})\right]^{2-}\left(6^{4-}\right)$.

Approximately $1 \mathrm{~nm}$ separated two semiquinone terminal ligands $\left(\mathrm{L}_{3}^{\bullet-}\right)$ in $\left[(\mathrm{Cl})\left(\mathrm{L}_{3}^{\bullet-}\right) \mathrm{Ru}^{\mathrm{II}}(\mu-\right.$ $\left.\left.\mathrm{BL}_{1}^{0}\right) \mathrm{Ru}^{\mathrm{II}}\left(\mathrm{L}_{3}^{\cdot-}\right)(\mathrm{Cl})\right](7)$ results in an uncoupled triplet $(\mathrm{S}=1)$ ground state with widely spread ${ }^{1} \mathrm{H}$ NMR signals in the chemical shift range of +23 to $-38 \mathrm{ppm}$ due to paramagnetic contact shifts. ${ }^{7 \mathrm{c}, \mathrm{d}, \mathrm{f}-\mathrm{h}, \mathrm{j}, 17}$ The compound 7 exhibits mostly quinone-ligand based redox activity within a narrow potential range, high intensity near-IR absorptions $\left(\lambda_{\max } \approx 920 \mathrm{~nm}, \varepsilon>\right.$ $\left.50,000 \mathrm{M}^{-1} \mathrm{~cm}^{-1}\right)$, variable intra- and intermolecular spin-spin interactions and ligand-based free radical EPR but without any half-field signal as expected for the bi-radical species. ${ }^{18}$ Three one-electron reduction and two one-electron oxidation processes of 7 within $\pm 2.0 \mathrm{~V} v s$ SCE in acetonitrile were probed by DFT calculations, EPR and spectroelectrochemistry (UV-VIS-NIR region). The semiquinone type EPR signature for the singly charged paramagnetic doublet ( $\mathrm{S}=1 / 2$ ) species, $\mathbf{7}^{+}$or $\mathbf{7}^{-}$reveals primarily quinonebased electron-transfer processes leading to the redox chain of $\left[(\mathrm{Cl})\left(\mathrm{L}_{3}^{0}\right) \mathrm{Ru}^{\mathrm{II}}\left(\mu-\mathrm{BL}_{1}^{0}\right) \mathrm{Ru}^{\mathrm{II}}\left(\mathrm{L}_{3}^{0}\right)(\mathrm{Cl})\right]^{2+}\left(7^{2+}\right) \rightleftharpoons$ $\left[(\mathrm{Cl})\left(\mathrm{L}_{3}^{\bullet-}\right) \mathrm{Ru}^{\mathrm{II}}\left(\mu-\mathrm{BL}_{1}^{0}\right) \mathrm{Ru}^{\mathrm{II}}\left(\mathrm{L}_{3}^{0}\right)(\mathrm{Cl})\right]^{+}\left(7^{+}\right) \rightleftharpoons\left[(\mathrm{Cl})\left(\mathrm{L}_{3}^{\bullet-}\right)\right.$ $\left.\operatorname{Ru}^{\mathrm{II}}\left(\mu-\mathrm{BL}_{1}^{0}\right) \mathrm{Ru}^{\mathrm{II}}\left(\mathrm{L}_{3}^{\bullet-}\right)(\mathrm{Cl})\right](7) \rightleftharpoons\left[(\mathrm{Cl})\left(\mathrm{L}_{3}^{\bullet-}\right) \mathrm{Ru}^{\mathrm{II}}(\mu-\right.$ $\left.\left.\mathrm{BL}_{1}^{0}\right) \mathrm{Ru}^{\mathrm{II}}\left(\mathrm{L}_{3}^{2-}\right)(\mathrm{Cl})\right]^{-}\left(7^{-}\right) \rightleftharpoons\left[(\mathrm{Cl})\left(\mathrm{L}_{3}^{2-}\right) \mathrm{Ru}^{\mathrm{II}}\left(\mu-\mathrm{BL}_{1}^{0}\right)\right.$ $\left.\mathrm{Ru}^{\mathrm{II}}\left(\mathrm{L}_{3}^{2-}\right)(\mathrm{Cl})\right]^{2-}\left(7^{2-}\right)$. However, unlike $7^{+}$, appreciable contribution from the metal-based orbitals has been evidenced in the singly occupied MO of $\mathbf{7}^{-}$.
Comparison of the redox series of $7^{\mathrm{n}}$ incorporating simple quinone ligand $\left(\mathrm{L}_{3}^{\mathrm{n}}\right)$ with the analogous series involving a more basic iminoquinone ligand $\left(\mathrm{L}_{2}^{\mathrm{n}}\right)$ in $\mathbf{6}^{\mathrm{n}}$ reveals significant variations particularly with respect to the redox potentials and metal-quinonoid interactions. In consequence, the reduction of the bridge $\left(\mathrm{BL}_{1}^{0}\right)$ in $7^{\mathrm{n}}$ takes place only after the complete reduction of the terminal semiquinone ligands to their catecholate states $\left(\mathrm{L}_{3}^{2-}\right)$ whereas in $6^{\mathrm{n}}$ bridge reduces prior to the iminosemiquinone ligands $\left(\mathrm{L}_{2}^{--}\right)$.

\section{5 p-Quinone bridged diruthenium system: A remote coupling between the paramagnetic metal centres in a three-spin metal-bridge-metal arrangement}

To understand the electron transfer behaviour of $p$-quinone bridged diruthenium system, the diastereomeric meso and rac complexes $\left[(\mathrm{acac})_{2} \mathrm{Ru}^{\mathrm{III}}(\mu\right.$ $\left.\left.\mathrm{BL}_{2}^{2-}\right) \mathrm{Ru}^{\mathrm{III}}(\mathrm{acac})_{2}\right], \quad \mathbf{8 a}$ and $\mathbf{8 b}$, respectively, $\left(\mathrm{BL}_{2}^{2-}=\right.$ 1,4-dioxido-2,3-bis(3,5-dimethylpyrazol-1/yl)benzene) were synthesized and structurally characterized. ${ }^{19}$ The electron-rich ancillary ligands $\left(\mathrm{acac}^{-}=\right.$

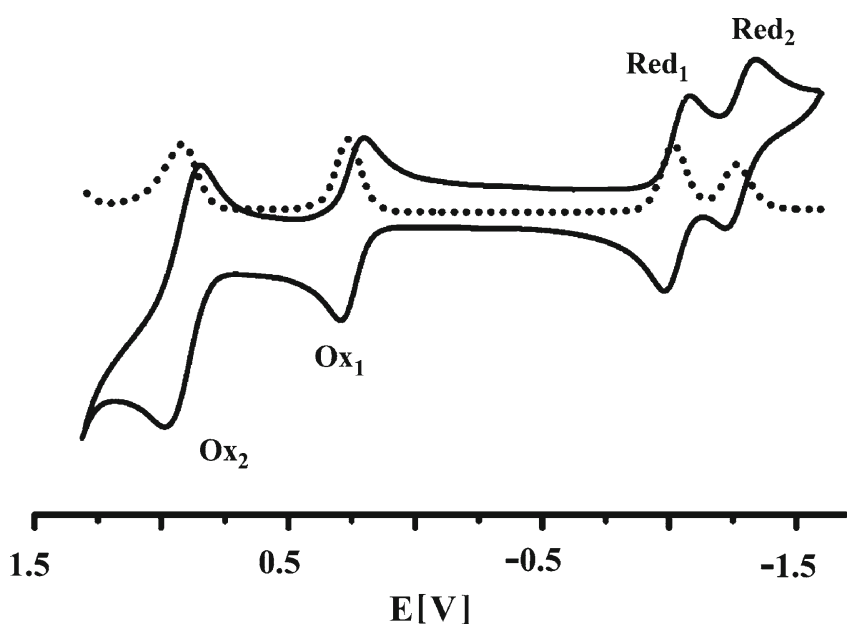

Figure 1. Cyclic voltammograms of $8 \mathbf{a}$ in $\mathrm{CH}_{3} \mathrm{CN} /$ $\left[\mathrm{Et}_{4} \mathrm{~N}\right]\left[\mathrm{ClO}_{4}\right]$ vs. SCE. 


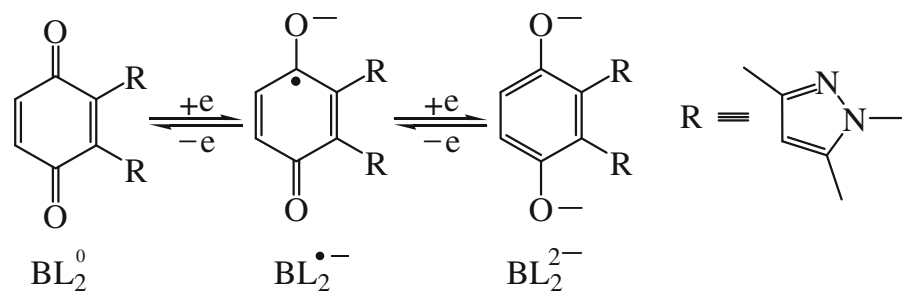

Scheme 6. Different redox forms of $\mathrm{BL}_{2}$.

acetylacetonato) and the fully reduced $\mathrm{BL}_{2}^{2-}$ collectively stabilize the ruthenium ions in +3 oxidation state in $\mathbf{8 a}$ or $\mathbf{8 b}$. The diastereomers, $\mathbf{8 a}$ and $\mathbf{8 b}$ exhibit

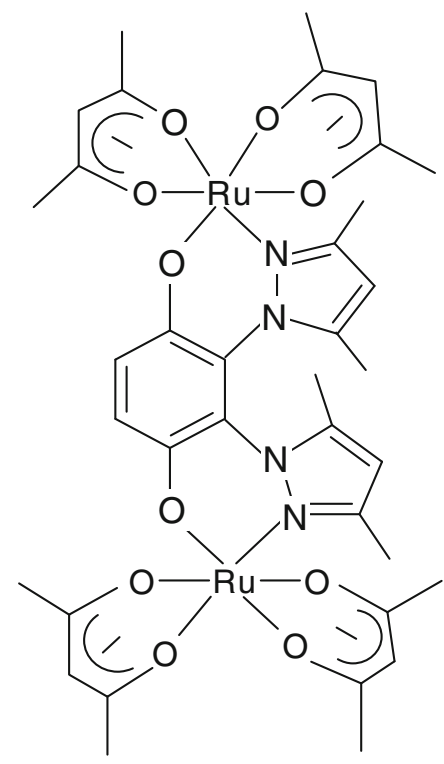

8a : rac isomer

$\mathbf{8 b}:$ meso isomer

slightly different $J$ values of $-37 \mathrm{~cm}^{-1}$ and $-21 \mathrm{~cm}^{-1}$, respectively, for the spin-spin interaction between the ca. $7.75 \AA$ separated $\mathrm{Ru}^{\mathrm{III}}$ centres. The diastereomeric complexes (8a and $\mathbf{8 b}$ ) also behave similarly with respect to their electrochemical and spectroscopic properties. They show successive two-step oxidation $\left(\mathrm{Ox}_{1}\right.$, $\left.\mathrm{Ox}_{2}\right)$ and two-step reduction processes $\left(\operatorname{Red}_{1}, \operatorname{Red}_{2}\right)$ (figure 1). The presence of fully reduced state $\left(\mathrm{BL}_{2}^{2-}\right.$, scheme 6) of the non-innocent bridging unit in the complexes suggests the natural involvement of the metal ions in the observed two-step reduction processes which generate $\mathrm{Ru}^{\mathrm{III}} \mathrm{Ru}^{\mathrm{II}}$ mixed valent intermediate $\left(\left[(\mathrm{acac})_{2} \mathrm{Ru}^{\mathrm{III}}\left(\mu-\mathrm{BL}_{2}^{2-}\right) \mathrm{Ru}^{\mathrm{II}}(\mathrm{acac})_{2}\right]^{-}, \mathbf{8 a}^{-}\right.$or $\left.\mathbf{8} \mathbf{b}^{-}\right)$with comproportionation constants $\left(\mathrm{RT} \ln K_{\mathrm{c}}=\right.$ $n F \Delta E^{20}$ ) of ca. $10^{4}$ followed by doubly reduced isovalent $\mathrm{Ru}^{\mathrm{II}} \mathrm{Ru}^{\mathrm{II}}\left(\left[(\mathrm{acac})_{2} \mathrm{Ru}^{\mathrm{II}}\left(\mu-\mathrm{BL}_{2}^{2-}\right) \mathrm{Ru}^{\mathrm{II}}(\mathrm{acac})_{2}\right]^{2-}, \mathbf{8 a}^{2-}\right.$ or $\mathbf{8 b ^ { 2 - }}$ ) state. The mixed valent $\mathbf{8 a}^{-}$or $\mathbf{8 b ^ { - }}$ exhibits anisotropic $\mathrm{Ru}^{\mathrm{III}}$-type rhombic EPR (figure 2a) and broad intervalence charge transfer (IVCT) bands (figure $3 \mathrm{a}$ ) in the range of $1200-1500 \mathrm{~nm}$, implying a valence localized class II situation ${ }^{21}$ which however expectedly disappears on further reduction to the isovalent $\mathrm{Ru}^{\mathrm{II}} \mathrm{Ru}{ }^{\mathrm{II}}$ state in $\mathbf{8 \mathbf { a } ^ { 2 - }}$ or $\mathbf{8} \mathbf{b}^{2-}$ (figure $3 b$ ).

The first oxidation however results in a free radical EPR with $g \approx 2.0$ (figure $2 b$ ). This is not compatible with the electronic structural situation of metal based oxidation to $\left[(\mathrm{acac})_{2} \mathrm{Ru}^{\mathrm{IV}}\left(\mu-\mathrm{BL}_{2}^{2-}\right) \mathrm{Ru}^{\mathrm{III}}(\mathrm{acac})_{2}\right]^{+}$ $\left(\mathbf{8} \mathbf{a}^{+}\right.$or $\left.\mathbf{8 b ^ { + }}\right)$ as it would expect to display a $\mathrm{Ru}(\mathrm{III})$ type anisotropic EPR. The alternate of $\mathrm{BL}_{2}^{2-}$ based oxidation to a three-spin arrangement in $\left[(\mathrm{acac})_{2} \mathrm{Ru}^{\mathrm{III}}(\mu\right.$ $\left.\left.\mathrm{BL}_{2}^{\bullet-}\right) \mathrm{Ru}^{\mathrm{III}}(\mathrm{acac})_{2}\right]^{+}\left(\mathbf{8 a}^{+}\right.$or $\left.\mathbf{8 b}^{+}\right)$with up-down-up $(\uparrow \downarrow \uparrow)$ spin configuration in the ground state would also result in a metal-centred spin through antiferromagnetic coupling between the adjacent spins

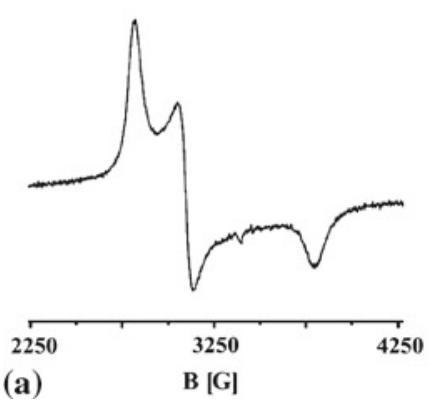

Figure 2. (a) EPR spectra of $\mathbf{8 a}^{-}$and (b) $\mathbf{8} \mathbf{a}^{+}$in $\mathrm{CH}_{3} \mathrm{CN} /\left[\mathrm{Bu}_{4} \mathrm{~N}\right]\left[\mathrm{PF}_{6}\right]$. 

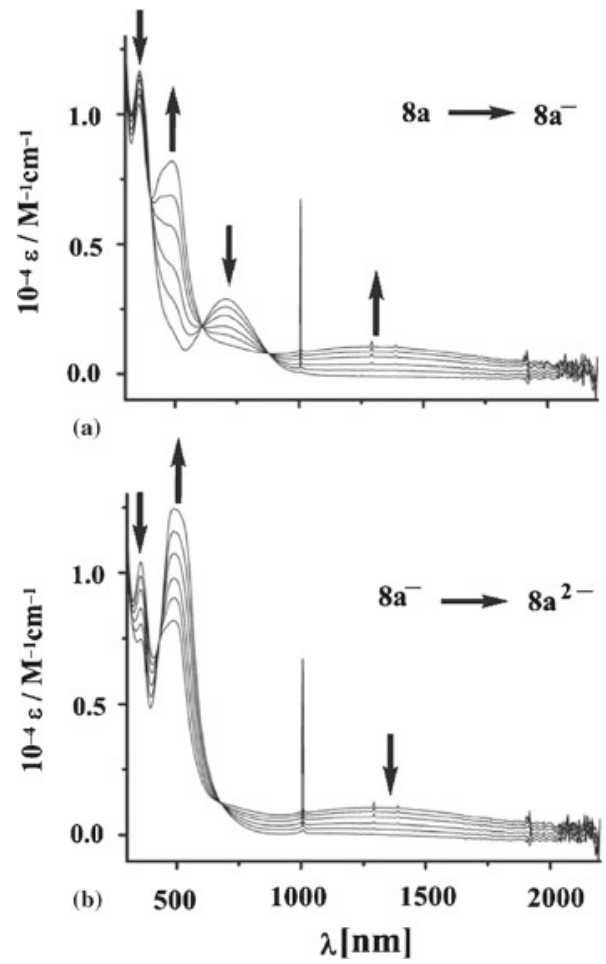

Figure 3. UV/VIS/NIR spectroelectrochemistry of (a) $\mathbf{8 a} \rightarrow \mathbf{8} \mathbf{a}^{-}$and (b) $\mathbf{8} \mathbf{a}^{-} \rightarrow \mathbf{8 a}^{2-}$ in $\mathrm{CH}_{3} \mathrm{CN} /\left[\mathrm{Bu}_{4} \mathrm{~N}\right]\left[\mathrm{PF}_{6}\right]$.

of $\mathrm{Ru}^{\mathrm{III}}$ and $\mathrm{BL}_{2}^{\cdot-}$. However, the same $\left\{\mathrm{Ru}^{\mathrm{III}}(\mu-\right.$ $\left.\left.\mathrm{BL}_{2}^{\bullet-}\right) \mathrm{Ru}^{\mathrm{III}}\right\}$ three-spin situation but an unusual upup-down ( $\uparrow \downarrow)$ spin configuration ${ }^{22}$ can account for the resultant ligand-centred spin through the strong antiferromagnetic coupling between the remote metal $\left(\mathrm{Ru}^{\mathrm{III}}\right)$ spins. This is being attributed to the weak adjacent metal $\left(\mathrm{Ru}^{\mathrm{III}}\right)$-radical $\left(\mathrm{BL}_{2}^{\bullet-}\right)$ coupling due to pyrazolyl/ $p$-semiquinone twist in coordinated $\mathrm{BL}_{2}$ as evidenced by the crystal structures of $\mathbf{8 a}$ and $\mathbf{8 b}$.

\subsection{Radical ligand bridged asymmetrical diruthenium complex: An EC process}

The asymmetrical diruthenium complex $\left[(\mathrm{acac})_{2}\right.$ $\left.\operatorname{Ru} 1\left(\mu-\mathrm{BL}_{3}\right) \mathrm{Ru} 2(\mathrm{Cym})(\mathrm{Cl})\right]\left(\mathrm{PF}_{6}\right)(9)\left(\mathrm{acac}^{-}=\right.$acetylacetonato, $\mathrm{BL}_{3}=2,2^{\prime}$-azobispyridine, and $\mathrm{Cym}=$ $p$-cymene $=1$-isopropyl-4-methylbenzene) was developed. ${ }^{23}$ The N-N bond distance of 1.352(3) $\AA$ in the

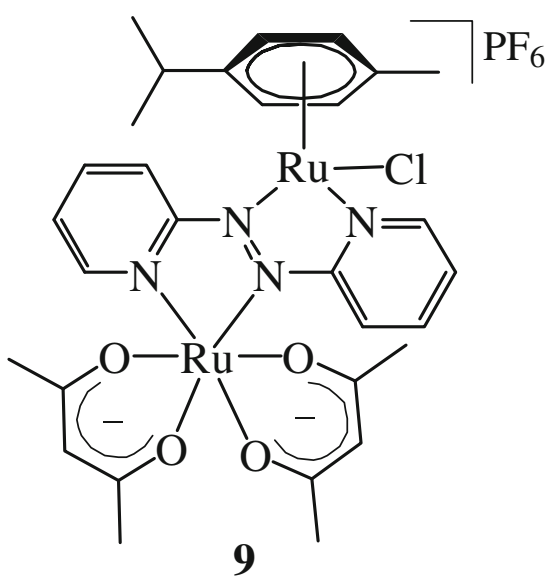

crystal of 9 reveals that $\mathrm{BL}_{3}$ exists in intermediate radical state (scheme 7$),{ }^{24}$ leading to a radical bridged mixed valent asymmetrical diruthenium complex, $\left[(\mathrm{acac})_{2} \mathrm{Ru} 1^{\mathrm{III}}\left(\mu-\mathrm{BL}_{3}^{--}\right) \mathrm{Ru} 2^{\mathrm{II}}(\mathrm{Cym}) \mathrm{Cl}\right]^{+}$. The presence of asymmetrical terminal ligands, $\sigma$-donating $\mathrm{acac}^{-}$and $\pi$-accepting $\mathrm{Cym}$ results in $\mathrm{Ru}(\mathrm{III})$ and $\mathrm{Ru}(\mathrm{II})$ sites, respectively, which also reflects in different $\mathrm{Ru}-\mathrm{N}\left(\mathrm{BL}_{3}^{\cdot-}\right)$ bond distances at the termini. The strong antiferromagnetic coupling between the unpaired spins on $\mathrm{Ru}^{\mathrm{III}}$ and $\mathrm{BL}_{3}^{\bullet-}$ yields a singlet $(\mathrm{S}=0)$ ground state.

In acetonitrile solution 9 exhibits successive two oxidations and three reductions. Bridging ligandbased first oxidation leads to the formation of $\left[(\mathrm{acac}){ }_{2} \mathrm{Ru} 1^{\mathrm{III}}\left(\mu-\mathrm{BL}_{3}^{0}\right) \mathrm{Ru} 2^{\mathrm{II}}(\mathrm{Cym}) \mathrm{Cl}\right]^{2+}\left(\mathbf{9}^{+}\right)$as evidenced by the metal-centred spin (EPR: $g_{1}=2.207$, $g_{2}=2.155, g_{3}=1.929$; Mulliken spin distribution: Ru1, 0.727; Ru2, 0; acac, 0.334; $\mathrm{BL}_{3},-0.038$ ). The mixed valent $\mathrm{Ru}^{\mathrm{III}} \mathrm{Ru}^{\mathrm{II}}$ state in $\mathbf{9}^{+}$exhibits a weak IVCT transition at $1700 \mathrm{~nm}$. The DFT-supported first reduction of 9 also occurs at the bridging ligand, $\left[(\mathrm{acac}){ }_{2} \mathrm{Ru} 1^{\mathrm{III}}\left(\mu-\mathrm{BL}_{3}^{2-}\right) \mathrm{Ru} 2^{\mathrm{II}}(\mathrm{Cym}) \mathrm{Cl}\right]\left(\mathbf{9}^{-}\right)$. However, the first reduction of $\mathbf{9}$ is not fully reversible as established by experimental results which undergoes the loss of chloride ion to form $\left[(\mathrm{acac})_{2} \mathrm{Ru} 1^{\mathrm{III}}(\mu\right.$ $\left.\left.\mathrm{BL}_{3}^{2-}\right) \mathrm{Ru} 2^{\mathrm{II}}(\mathrm{Cym})\right]^{+}=\mathbf{9 a}$ with metal based EPR, $g_{1}=$ 2.454, $g_{2}=2.032$ and $g_{3}=1.947$ (an EC process: electron transfer induced chemical transformation). ${ }^{25}$ Further reduction to the $\mathrm{Ru} 1^{\mathrm{III}}$ site produces $\left[(\mathrm{acac})_{2}\right.$ $\left.\mathrm{Ru} 1^{\mathrm{II}}\left(\mu-\mathrm{BL}_{3}^{2-}\right) \mathrm{Ru} 2^{\mathrm{II}}(\mathrm{Cym})\right]=\mathbf{9 a}{ }^{-}$which on subsequent reduction forms $\left[(\mathrm{acac})_{2} \mathrm{Ru} 1^{\mathrm{II}}\left(\mu-\mathrm{BL}_{3}^{2-}\right) \mathrm{Ru} 2^{\mathrm{I}}\right.$

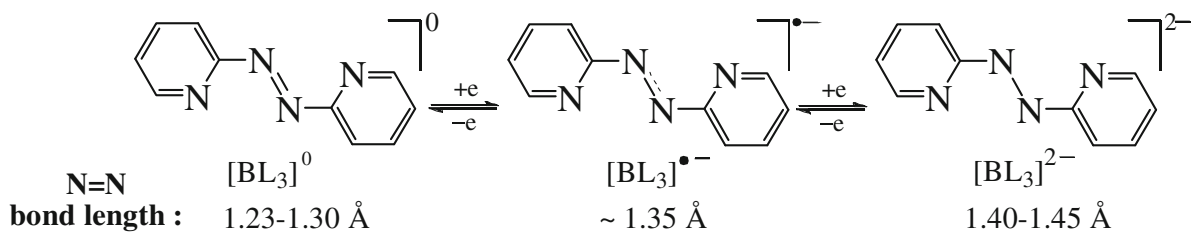

Scheme 7. Different redox states of $\mathrm{BL}_{3}$ and characteristic $\mathrm{N}=\mathrm{N}$ distances. 
$(\mathrm{Cym})]^{-} \leftrightarrow\left[(\mathrm{acac})_{2} \mathrm{Ru}^{\mathrm{II}}\left(\mu-\mathrm{BL}_{3}^{\bullet-}\right) \mathrm{Ru}^{0}(\mathrm{Cym})\right]^{-}=\mathbf{9 a}^{2-}$ with a free radical EPR signature.

\section{Conclusion and outlook}

The fundamental event of determining the electronic structural aspects of metal complexes with noninnocent ligands has been highlighted using recently reported selective ruthenium-based molecular frameworks as model systems. In spite of the fact of built in complications, the delicate valence and spin situations of such complexes can be addressed with reasonable level of confidence via parallel experimental and high level theoretical investigations. Besides the understanding of complex biological electron-transfer processes, this sort of multielectronic platform has recently been established to function as potential electron reservoir for catalytic reactions. ${ }^{26}$ However, further studies with more challenging molecular frameworks would certainly facilitate to unfold the newer insights.

\section{Acknowledgements}

Financial support received from the Department of Science and Technology (DST) and the Council of Scientific and Industrial Research (CSIR) (fellowship to AD), New Delhi, is gratefully acknowledged. We thank Prof. W. Kaim, Stuttgart University, Germany for valuable inputs.

\section{References}

1. Jørgensen C K 1966 Coord. Chem. Rev. 1164

2. Ward M D and McCleverty J A 2002 J. Chem. Soc. Dalton Trans. 275

3. McCleverty J A and Ward M D 1998 Acc. Chem. Res. 31842

4. (a) Kaim W 2011 Inorg. Chem. 50 9572; (b) Poddelsky A I, Cherkasov V V and Abakumov G A 2009 Coord. Chem. Rev. 253 291; (c) Herebian D, Bothe E, Bill E, Weyhermüller T and Wieghardt K $2001 \mathrm{~J}$. Am. Chem. Soc. 12310012

5. Seddon E A and Seddon K R 1984 The chemistry of ruthenium (Oxford: Elsevier) p. 203

6. (a) Masui H, Freda A L, Zerner M C and Lever A B P 2000 Inorg. Chem. 39 141; (b) Roy N, Sproules S, Weyhermueller T and Wieghardt K 2009 Inorg. Chem. 48 3783; (c) Barthram A M, Clear L, Kowallick R and Ward M D 1998 Chem. Commun. 2695; (d) Roy S, Sarkar B, Bubrin D, Niemeyer M, Záliš S, Lahiri G K and Kaim W 2008 J. Am. Chem. Soc. 130 15230; (e) Patra S C, Biswas M K, Maity A N and Ghosh P 2011 Inorg. Chem. 50 1331; (f) Roy A S, Saha P, Das Adhikary N and Ghosh P 2011 Inorg. Chem. 50 2488; (g) Roy A S, Tuononen H M, Rath S P and Ghosh P 2007
Inorg. Chem. 46 5942; (h) Das D, Mondal T K, Mobin S M and Lahiri G K 2009 Inorg. Chem. 48 9800; (i) Maji S, Patra S, Chakraborty S, Janardanan D, Mobin S M, Sunoj R B and Lahiri G K 2007 Eur. J. Inorg. Chem. 314; (j) Pierpont C G 2001 Coord. Chem. Rev. 219-221 415; (k) Kalinina D, Dares D, Kaluarachchi H, Potvin P G and Lever A B P 2008 Inorg. Chem. 4710110

7. (a) Kaim W and Lahiri G K 2007 Angew. Chem. Int. Ed. 46 1778; (b) Maji S, Sarkar B, Patra S, Fiedler J, Mobin S M, Puranik V G, Kaim W and Lahiri G K 2006 Inorg. Chem. 45 1316; (c) Maji S, Sarkar B, Mobin S M, Fiedler J, Urbanos F A, Jimenez-Aparicio R, Kaim W and Lahiri G K 2008 Inorg. Chem. 47 5204; (d) Ghumaan S, Sarkar B, Maji S, Puranik V G, Fiedler J, Urbanos F A, Jimenez-Aparicio R, Kaim W and Lahiri G K 2008 Chem. Eur. J. 14 10816; (e) Ghumaan S, Mukherjee S, Kar S, Roy D, Mobin S M, Sunoj R B and Lahiri G K 2006 Eur. J. Inorg. Chem. 4426; (f) Kar S, Sarkar B, Ghumaan S, Janardan D, Slageren J V, Fiedler J, Puranik V G, Sunoj R B, Kaim W and Lahiri G K 2005 Chem. Eur. J. 11 4901; (g) Patra S, Miller T A, Sarkar B, Niemeyer B M, War M D and Lahiri G K 2003 Inorg. Chem. 42 4707; (h) Kar S, Sarkar B, Ghumaan S, Roy D, Urbanos F A, Fiedler J, Sunoj R B, Jimenez-Aparicio R, Kaim W and Lahiri G K 2005 Inorg. Chem. 44 8715; (i) Kumbhakar D, Sarkar B, Das A, Das A K, Mobin S M, Fiedler J, Kaim W and Lahiri G K 2009 Dalton Trans. 9645; (j) Patra S, Sarkar B, Maji S, Fiedler J, Urbanos F A, Jimenez-Aparicio R, Kaim W and Lahiri G K 2006 Chem. Eur. J. 12 489; (k) Kar S, Sarkar B, Ghumaan S, Leboschka M, Fiedler J, Kaim W and Lahiri G K 2007 Dalton Trans. 1934

8. Remenyi C and Kaupp M 2005 J. Am. Chem. Soc. 127 11399

9. (a) Verani C N, Gallert S, Bill E, Weyhermüller T, Wieghardt K and Chaudhuri P 1999 Chem. Commun. 1747; (b) Chun H, Verani C N, Chaudhuri P, Bothe E, Bill E, Weyhermüller T and Wieghardt K 2001 Inorg. Chem. 40 4157; (c) Chun H, Chaudhuri P, Weyhermüller T and Wieghardt K 2002 Inorg. Chem. 41 790; (d) Sun X, Chun H, Hildenbrand K, Bothe E, Weyhermüller T, Neese F and Wieghardt K 2002 Inorg. Chem. 41 4295; (e) Chun H, Weyhermüller T, Bill E and Wieghardt K 2001 Angew. Chem. Int. Ed. 40 2489; (f) Samanta S, Singh P, Fiedler J, Záliš S, Kaim W and Goswami S 2008 Inorg. Chem. 47 1625; (g) Chatterjee S, Singh P, Fiedler J, Bakova R, Záliš S, Kaim W and Goswami S 2009 Dalton Trans. 7778; (h) Ghosh P, Bill E, Neese F, Weyhermüller T and Wieghardt K $2003 \mathrm{~J}$. Am. Chem. Soc. 1251293

10. (a) Patra S, Sarkar B, Mobin S M, Kaim W and Lahiri G K 2003 Inorg. Chem. 42 6469; (b) Das D, Das A K, Sarkar B, Mondal T K, Mobin S M, Fiedler J, Záliš S, Urbanos F A, Jiménez-Aparicio R, Kaim W and Lahiri G K 2009 Inorg. Chem. 4811853

11. Bhattacharya S, Gupta P, Basuli F and Pierpont C G 2002 Inorg. Chem. 415810

12. Das A, Scherer T, Maji S, Mondal T K, Mobin S M, Urbanos F A, Jiménez-Aparicio R, Kaim W and Lahiri G K 2011 Inorg. Chem. 507040

13. Das D, Mondal T K, Dutta Chowdhury A, Weisser F, Schweinfurth D, Sarkar B, Mobin S M, Urbanos F A, 
Jiménez-Aparicio R and Lahiri G K 2011 Dalton Trans. 408377

14. (a) Das A K, Sarkar B, Fiedler J, Záliš S, Hartenbach I, Strobel S, Lahiri G K and Kaim W 2009 J. Am. Chem. Soc. 131 8895; (b) Kundu T, Sarkar B, Mondal T K, Mobin S M, Urbanos F A, Fiedler J, Jiménez-Aparicio R, Kaim W and Lahiri G K 2011 Inorg. Chem. 504753

15. (a) Ghumaan S, Sarkar B, Chanda N, Sieger M, Fiedler J, Kaim W and Lahiri G K 2006 Inorg. Chem. 45 7955; (b) Koley M, Sarkar B, Ghumaan S, Bulak E, Fiedler J, Kaim W and Lahiri G K 2007 Inorg. Chem. 46 3736; (c) Hartshorn V, Daire N, Tondreau V, Loeb B, Meyer T J and White P S 1999 Inorg. Chem. 38 3200; (d) Chanda N, Laye R H, Chakraborty S, Paul R L, Jeffery J C, Ward M D and Lahiri G K 2002 J. Chem. Soc. Dalton Trans. 3496; (e) Rocha R C, Rein F N, Jude H, Shreve A P, Concepcion J J and Meyer T J 2008 Angew. Chem., Int. Ed. 47 503; (f) Kundu T, Sarkar B, Mondal T K, Fiedler J, Mobin S M, Kaim W and Lahiri G K 2010 Inorg. Chem. 496565

16. Das D, Sarkar B, Mondal T K, Mobin S M, Fiedler J, Kaim W and Lahiri G K 2011 Inorg. Chem. 507090

17. Koiwa T, Masuda Y, Shono J, Kawamoto Y, Hoshino Y, Hashimoto T, Natarajan K and Shimizu K 2004 Inorg. Chem. 436215

18. (a) Ozarowski A, McGarvey B R, Peppe C and Tuck D G 1991 J. Am. Chem. Soc. 113 3288; (b) Hosmane N S, Wang Y, Zhang H, Lu K-J, Maguire J A, Gray T G, Brooks K A, Waldhor E, Kaim W and Kremer R K 1997 Organometallics 16 1365; (c) Atherton N M 1973 Electron spin resonance (Sussex, England: Ellis Horwood, Ltd.)

19. Kumbhakar D, Sarkar B, Maji S, Mobin S M, Fiedler J, Urbanos F A, Jimenez-Aparicio R, Kaim W and Lahiri G K 2008 J. Am. Chem. Soc. 13017575
20. Creutz C 1983 Prog. Inorg. Chem. 301

21. Robin M B and Day P 1967 Adv. Inorg. Chem. Radiochem. 10247

22. Chaudhuri P, Verani C N, Bill E, Bothe E, Weyhermueller T and Wieghardt K 2001 J. Am. Chem. Soc. 123 2213

23. Das A, Scherer T M, Dutta Chowdhury A, Mobin S M, Kaim W and Lahiri G K 2012 Inorg. Chem. 511675

24. (a) Sarkar B, Patra S, Fiedler J, Sunoj R B, Janardanan D, Mobin S M, Niemeyer M, Lahiri G K and Kaim W 2005 Angew. Chem. Int. Ed. 44 5655; (b) Sarkar B, Patra S, Fiedler J, Sunoj R B, Janardanan D, Lahiri G K and Kaim W 2008 J. Am. Chem. Soc. 1303532

25. (a) Sixt T, Sieger M, Krafft M J, Bubrin D, Fiedler J and Kaim W 2010 Organometallics 29 5511; (b) Kaim W, Sixt T, Weber M and Fiedler J 2001 J. Organomet. Chem. 637-639 167; (c) Kaim W, Reinhardt R and Sieger M 1994 Inorg. Chem. 33 4453; (d) Kaim W, Reinhardt R, Greulich S and Fiedler J 2003 Organometallics 22 2240; (e) Greulich S, Kaim W, Stange A F, Stoll H, Fiedler J and Záliš S 1996 Inorg. Chem. 35 3998; (f) Scheiring T, Fiedler J and Kaim W 2001 Organometallics 20 1437; (g) Kölle U and Grätzel M 1987 Angew. Chem. Int. Ed. 26 567; (h) Ladwig M and Kaim W 1991 J. Organomet. Chem. 419 233; (i) Ziessel R 1993 J. Am. Chem. Soc. 115118

26. (a) Tsai M-K, Rochford J, Polyansky D E, Wada T, Tanaka K, Fujita E and Muckerman J T 2009 Inorg. Chem. 48 4372; (b) Muckerman J T, Polyansky D E, Wada T, Tanaka K and Fujita E 2008 Inorg. Chem. 47 1787; (c) Wada T, Tsuge K and Tanaka K 2001 Inorg. Chem. 40 329; (d) Wada T, Tsuge K and Tanaka K 2000 Angew. Chem. Int. Ed. 39 1479; (e) Sala X, Romero I, Rodríguez M, Escriche L and Llobet A 2009 Angew. Chem., Int. Ed. 482842 